\title{
Converting enzyme inhibitors in hypertension and heart failure
}

\author{
H J DARGIE, S G BALL, A B ATKINSON, J I S ROBERTSON \\ From MRC Blood Pressure Unit and Department of Cardiology, Western Infirmary, Glasgow; and Metabolic Unit, \\ Royal Victoria Hospital, Belfast
}

The renin-angiotensin-aldosterone system is intimately involved in the regulation of vascular tone, and is central to sodium homeostasis; the octapeptide angiotensin II, formed by the action of converting enzyme on the inactive precursor decapeptide angiotensin I, constricts arterioles, enhances sympathetic activity, and promotes sodium retention, both by direct renal actions and through the release of aldosterone.

Hypertension and cardiac failure are characterised by increased peripheral vascular tone and abnormal sodium and water excretion, though to what extent these changes reflect activity of the reninangiotensin-aldosterone system is unclear. Both con= ditions respond to diuretics and vasodilators even though consequent stimulation of the reninangiotensin-aldosterone system may ensue. Not surprisingly, therefore, the recent introduction of orally active converting enzyme inhibitors ${ }^{12}$ has generated much renewed interest in the role of the reninangiotensin-aldosterone system in hypertension and cardiac failure. These drugs prevent the conversion of angiotensin I to angiotensin II. They may also have additional effects such as inhibition of degradation of the vasodilator peptide bradykinin. Though most of our knowledge concerning the effects of converting enzyme inhibitors in man stems from the use of captopril, preliminary work with the newer compound enalapril (MK421) suggests that it has similar pharmacological effects. ${ }^{3}$ Both drugs reduce plasma angiotensin II and aldosterone with reciprocal changes in plasma renin and angiotensin I concentrations. Sustained suppression of plasma angiotensin II has been seen using $150 \mathrm{mg}$ captopril three times a day. ${ }^{4}$ Enalapril, which has a longer action, may be given less frequently. ${ }^{3}$ The associated early fall in blood pressure is the result of reduction in peripheral vascular resistance which is probably largely, though perhaps not entirely, the result of the reduction in plasma angiotensin II since restoration of the latter by infusion of exogenous angiotensin II does not reverse completely the hypotensive effects of captopril. ${ }^{5}$ With prolonged use, a further fall of pressure may occur over one to three weeks; this may be the partial result of antagonism of a slow pressor effect of angiotensin II. ${ }^{3}$

Thus, there may be actions of converting enzyme inhibition on the systemic vasculature other than loss of the direct vasoconstrictor effect of angiotensin II; candidates for involvement in these mechanisms include bradykinin, prostaglandins, and the sympathetic nervous system, while resetting of baroreflexes has also been suggested. ${ }^{16^{-8}}$ Inhibition of bradykinin degradation by converting enzyme inhibitors could have two principal results; firstly, increased levels of bradykinin could directly result in vasodilatation; and, secondly, stimulation of prostaglandin $\mathrm{E}$ production could result in further vasodilatation. The evidence, however, for involvement of kinins or prostaglandins in the pharmacological effects of converting enzyme inhibitors is conflicting. 910

In hypertension, converting enzyme inhibitors ought to be most effective when plasma angiotensin II is raised. Indeed, precipitous falls in pressure can occur when renin and angiotensin II are very high as in some patients with malignant phase hypertension, or after intensive diuretic therapy.11-13 Salt-depleted normal subjects show similarly enhanced responses to inhibition of converting enzyme. ${ }^{12}$ When captopril is administered to patients with renovascular hypertension, many of whom have increased plasma levels of renin and angiotensin II, there is an initial fall in blood pressure proportional both to the plasma concentration of renin and angiotensin II, and to the fall in angiotensin II after dosing. With long-term treatment, there is often a further reduction..$^{13-15}$

The haemodynamic effects of captopril in essential and renovascular hypertension are similar, comprising a fall in peripheral vascular resistance and cardiac 
filling pressure with no significant change in heart rate or cardiac output. ${ }^{16}$ Thus, converting enzyme inhibitors also reduce the blood pressure in patients with essential hypertension and their effects can be enhanced by diuretics. ${ }^{11} 12$ Indeed, a principal effect of this class of compounds could be facilitation of the hypotensive effect of diuretics since this action is limited by reactive stimulation of the reninangiotensin system. ${ }^{1317}$ As both sodium status and the renin-angiotensin system are critically involved in the maintenance of arterial pressure, ${ }^{1819}$ the therapeutic use of a converting enzyme inhibitor, a diuretic, or the two together has obvious attractions both in theory and practice. Certainly in many patients resistant to conventional antihypertensives, the combination of a converting enzyme inhibitor with a diuretic has proved to be particularly effective. ${ }^{11} 12$

Increased peripheral vascular resistance also commonly accompanies heart failure, and vasodilators are now well established in its treatment. Plasma renin is raised in many such patients ${ }^{20}$ and thus specific interference with at least one of the mechanisms leading to vasoconstriction can be achieved with converting enzyme inhibitors. The acute haemodynamic effects of captopril in heart failure comprise an increase in stroke volume, cardiac output, and stroke work index associated with a fall in systemic vascular resistance, left ventricular filling pressure, pulmonary arterial pressure, and right atrial pressure. While total pulmonary vascular resistance falls because of a reduction in pulmonary capillary pressure, pulmonary arteriolar pressure is unaffected. ${ }^{21-24}$ The fall in right atrial pressure seems greater than would result from the modest increase in cardiac output, but evidence for a direct venodilator effect is conflicting and angiotensin II does not normally constrict veins. ${ }^{25}$ Qualitatively the effects of captopril are similar to those of prazosin, though captopril also reduces the heart rate.

The clinical effects of captopril in cardiac failure include symptomatic improvement ${ }^{212226}$ (though these observations await confirmation in controlled trials) and an increase in maximum exercise capacity 212326 ; the rate pressure product at the end of this longer period of exercise is similar to or lower than control values, indicating more efficient energy utilisation. ${ }^{212627}$ These observations have recently been confirmed in a single blind study ${ }^{27}$; longer term experience also is encouraging. ${ }^{21} 2326$

Is captopril just another vasodilator? Even a casual glance at the varied physiological effects of angiotensin II tempts us to suspect that it may possess additional beneficial properties in heart failure. The acute haemodynamic effects correlate closely with the reduction in systemic vascular resistance and, though angiotensin II is a potent vasoconstrictor and its pro- duction is directly related to renin secretion, there is no consensus on the relation between plasma renin activity or concentration and the beneficial effect of captopril on cardiac function. ${ }^{22-24}$ This is less surprising when it is remembered that plasma renin can be normal in heart failure before treatment with diuretics; after diuretics, renin may rise, fall, or remain within the normal range. ${ }^{20}$ The increased systemic vascular resistance in heart failure in part may be the result of increased adrenergic activity either from a centrally mediated increase in sympathetic tone or possibly from a decrease in neuronal uptake of noradrenaline. ${ }^{28}$ Experimentally, angiotensin II can stimulate sympathetic activity in several ways both centrally and peripherally..$^{29} 30$ Preliminary studies in heart failure show that plasma noradrenaline may fall during treatment with captopril ${ }^{31}$; but to what extent this reflects a direct action of angiotensin II on sympathetic pathways or is merely the result of improvement in cardiac function remains to be clarified.

Other effects of angiotensin II, inhibition of which could be beneficial in heart failure, include stimulation of aldosterone and vasopressin secretion. But after captopril, at least initially, weight gain may occur $^{32}$ which can sometimes be pronounced. Perhaps reduction of renal perfusion pressure caused by the hypotensive effects of captopril, which occurs also in heart failure, exceeds the autoregulatory ability of the kidney to maintain renal blood flow and glomerular filtration rate. Moreover, while it is known that peripheral angiotensin II is effectively lowered by captopril, less is known about the suppression of the intrarenal formation of angiotensin II, and thus of modifications of tone in afferent and efferent arterioles, and the vasa recta, or on tubular sodium reabsorption. ${ }^{13}$

We have been impressed with the clinical effects of captopril in patients with intractable heart failure but many questions remain unanswered. These include whether the drug will influence appreciably long term survival given the serious underlying pathology leading to myocardial failure. The one year mortality in heart failure is high and death is often sudden, presumably because of serious ventricular arrhythmia. Recent evidence suggests that improvement of ventricular function and reduction of left ventricular dimensions are associated with a decrease in ventricular arrhythmias. ${ }^{33}$

Reduction in blood pressure, the object of treatment in hypertension, also occurs during treatment of heart failure with captopril. Much lower pressures, however, are tolerated in heart failure, in which, in contrast to hypertension, there is no upward resetting of the pressor limits of autoregulation of cerebral blood flow. ${ }^{34}$ Thus, in heart failure, hypotension is usually asymptomatic. Orthostatic hypotension is 
rare, as is reflex tachycardia, though the latter can occur occasionally in hypertensive patients on standing. Plasma potassium increases probably because of aldosterone suppression ${ }^{1314}$ and so potassium supplements and potassium sparing diuretics are usually contraindicated.

While these effects are to be expected with any converting enzyme inhibitor, there are some apparently specific adverse effects of captopril which have delayed its easy introduction into clinical practice. Skin rashes, fever, and transient loss of taste have been reported, which have usually resolved on withdrawal of treatment, or on occasion when treatment has continued. Proteinuria and membranous glomerulonephritis have also been reported but a recent review of renal biopsies from patients with hypertension, some of whom were receiving captopril, has emphasised the need for caution in attributing glomerular disease to drugs in the absence of pretreatment histology. ${ }^{35}$ Leukopenia and fatal agranulocytosis have been seen in a few cases, usually associated with serious intercurrent illness. ${ }^{36}$

These side effects, which are similar to those observed with penicillamine, a drug which also has a sulphydryl group, are almost certainly related to chemical structure rather than to mode of action. Captopril is excreted by the kidney and serious reactions usually have occurred in patients with renal impairment taking large doses of the drug. ${ }^{36}$ The dose response relations of captopril in hypertension and cardiac failure are not well defined but low doses (less than $150 \mathrm{mg}$ per day), adjusted downwards if renal function is impaired, are probably adequate. These lower doses might well minimise side effects. The results of current clinical studies using converting enzyme inhibitors without a thiol group are awaited.

The converting enzyme inhibitors are likely to have a major impact on the future treatment of hypertension and heart failure. Not only have they provided a new therapeutic initiative, but also, and of perhaps greater interest, they have given us a novel and subtle pharmacological probe with which to investigate specific mechanisms in the pathophysiology of these diverse but often related conditions. As in hypertension, could there be subsets of patients with heart failure who will respond particularly well to these agents? Further, is it possible that stimulation of the renin-angiotensin system in early cardiac failure is a helpful compensatory mechanism, and that converting enzyme inhibition might at that stage be harmful? 13 The answers to these and other questions await us in what promises to be a stimulating period of clinical research.

\section{References}

1 Ondetti MA, Rubin B, Cushman DW. Design of specific inhibitors of antiotensin-converting enzyme: new class of orally active antihypertensive agents. Science 1977; 196: 441-4.

2 Patchett AA, Harris E, Tristram EW, et al. A new class of angiotensin converting enzyme inhibitors. Nature 1980; 288: 280-3.

3 Hodsman GP, Brown JJ, Davies DL, et al. Converting-enzyme inhibitor enalapril (MK421) in treatment of hypertension with renal artery stenosis. $\mathrm{Br}$ Med f 1982; 285: 1697-9.

4 Atkinson $\mathrm{AB}$, Cumming AMM, Brown JJ, et al . Captopril treatment: inter-dose variations in renin, angiotensins I and II, aldosterone and blood pressure. $\mathrm{Br} \mathcal{F}$ Clin Pharmacol 1982; 13: 855-8.

5 Morton JJ, Tree M, Casals-Stenzel J. Effect of infused captopril on blood pressure and the renin-angiotensinaldosterone system in normal dogs subjected to varying sodium balance. Am f Cardiol 1982; 49: 1395-400.

6 Murthy VS, Waldron TL, Goldberg ME. The mechanism of bradykinin potentiation after inhibition of angiotensin-converting enzyme by SQ 14,225 in conscious rabbits. Circ Res 1978; 43, suppl 1:1-40-5.

7 Antonaccio MJ, Kerwin L. Evidence for prejunctional inhibition of norepinephrine release by captopril in spontaneously hypertensive rats. Eur $\mathcal{F}$ Pharmacol 1980; 68: 209-12.

8 Conway J, Hatton R, Keddie J, Dawes P. The role of angiotensin in the control of blood pressure during sodium depletion. Hypertension 1979; 1: 402-9.

9 Johnston CI, Yasujima $M$, Clappison BH. The kallikrein-kinin system and angiotensin converting enzyme inhibition in hypertension. In: Horovitz ZP, ed. Angiotensin converting enzyme inhibitors-mechanisms of action and clinical implications. Baltimore \& Munich: Urban and Schwarzenberg, 1981:123-39.

10 Swartz SL, Williams GH, Hollenberg NK, Moore TJ, Dluhy RG. Converting enzyme inhibition in essential hypertension: the hyptensive response does not reflect only reduced angiotensin II formation. Hypertension 1979; 1: 106-11.

11 White NJ, Yahaya H, Rajagopalan B, Ledingham JGG. Captopril and frusemide in severe resistant hypertension. Lancet 1980; ii: 108-10.

12 Atkinson AB, Brown JJ, Lever AF, Robertson JIS. Combined treatment of severe intractable hypertension with captopril and diuretic. Lancet 1980: ii: 105-8.

13 Atkinson AB, Robertson JIS. Captopril in the treatment of clinical hypertension and cardiac failure. Lancet 1979; ii: $836-9$.

14 Case DB, Atlas SA, Laragh JH, Sealey JE, Sullivan PA, McKinstry DN. Clinical experience with blockade of the renin-angiotensin-aldosterone system with an oral converting-enzyme inhibitor (SQ 14,225; captopril) in hypertensive patients. Prog Cardiovasc Dis 1978; 21: 195-206.

15 Atkinson AB, Brown JJ, Fraser R, et al. Captopril in hypertension with renal artery stenosis and in intractable hypertension: acute and chronic changes in circulating concentrations of renin, angiotensins I and II and aldosterone, and in body composition. Clin Sci 1979; 57: $139 \mathrm{~s}-43 \mathrm{~s}$.

16 Wenting GJ, de Bruyn JHB, Man in t'Veld AJ, Woittiez AJJ, Derkx FHM, Schalekamp ADH. Hemodynamic 
effects of captopril in essential hypertension, renovascular hypertension and cardiac failure: correlations with short- and long-term effects on plasma renin. Am $\mathcal{Y ~ C a r - ~}$ diol 1982; 49: 1453-9.

17 Leonetti G, Terzoli L, Sala C, Bianchini C, Sernesi L, Zanchetti A. Relationship between the hypotensive and renin stimulating actions of diuretic therapy in hypertensive patients. Clin Sci Mol Med 1978; 55: 307s-9s.

18 Robertson JIS, Wilhelmson L, Morgan TO, et al. Round Table 2. Proceedings of the 6th Meeting of the International Society of Hypertension. Salt intake and the pathogenesis and treatment of hypertension. Clin Sci 1979; 57, suppl 5:453s-80s.

19 Brown JJ, Casals-Stenzel J, Cumming AMM, et al. Angiotensin II, aldosterone and arterial pressure: a quantitative approach. Hypertension 1979; 1: 159-79.

20 Brown JJ, Davies DL, Johnson VW, Lever AF, Robertson JIS. Renin relationships in congestive cardiac failure, treated and untreated. Am Heart $\mathcal{F}$ 1970; 80: 329-42.

21 Ader R, Chatterjee K, Ports T, Brundage B, Hiramatsu B, Parmley $W$. Immediate and sustained hemodynamic and clinical improvement in chronic heart failure by an oral angiotensin-converting enzyme inhibitor. Circulation 1980; 61: 931-7.

22 Levine TB, Franciosa JA, Cohn JN. Acute and long term response to an oral converting enzyme inhibitor, captopril, in congestive heart failure. Circulation 1980; 62: $35-41$.

23 Sharpe DN, Coxon RJ, Douglas JE, Long B. Low-dose captopril in chronic heart failure: acute haemodynamic effects and long-term treatment. Lancet 1980; ii: 1154-7.

24 Ceimo JM, Fouad FM, Bravo EL, Tarazi RC. Acute effects of converting enzyme inhibitor (CEI) in congestive heart failure (CHF). Circulation 1979; $59 \& 60$, suppl II: 83.

25 Cohn JN. Relationship of plasma volume changes to resistance and capacitance vessel effects of sympathomimetic amines and angiotensin in man. Clin Sci 1966; 30: 267-78.

26 Awan NA, Evenson MK, Needham, Win A, Mason DT.
Efficacy of oral angiotensin-converting enzyme inhibition with captopril therapy in severe chronic normotensive congestive heart failure. Am Heart f 1980; 101: 22-31.

27 Cowley AJ, Rowley JM, Stainer KL, Hampton JR. Captopril therapy for heart failure. Lancet 1982; ii: 703-2.

28 Dietz, R. Humeral adaptation mechanisms in heart failure. In: Goodwin JF, Hjalmarson A, Olsen EGJ, eds. Congestive cardiomyopathy. Sweden: AB Hassle, Mölndal, 1981: 128.

29 Joy MD. The intramedullary connections of the area postrema involved in the central cardiovascular response to angiotensin II. Clin Sci 1971; 41: 89-100.

30 McCubbin JW, Page IH. Renal pressor system and neurogenic control of arterial pressure. Circ Res 1963; 12: 553-9.

31 Turini GA, Brunner HR, Gribic M, Waeber B, Gavras $H$. Improvement of chronic congestive heart-failure by $\vec{c}$ oral captopril. Lancet 1979; i: 1213-5.

32 Pierpont GL, Francis GS, Cohn JN. Effect of captopril on renal function in patients with congestive heart fail- $\mathrm{G}$ ure. Br Heart $\mathcal{F}$ 1981; 46: 522-7.

33 Cleland JGF, Dargie HJ, McLeod Kay, et al. Arrhythmia in heart failure: effect of improved left ventricular $>$ function. $\mathcal{A}$ Am Coll Cardiol 1983; in press.

34 Graham DI, Jones JV. Hypertension and the cerebral circulation with special reference to the pathophysiology $\vec{\emptyset}$ of central nervous complications of treatment. Royal Soc- $\omega$ iety of Medicine International Congress and Symposium Series 1980; 26: 105-13.

35 Captopril Collaborative Study Group. Does captopril cause renal damage in hypertensive patients? Lancet 1982; i: 988-90.

36 Heel RC, Brogden RN, Speight TM, Avery GS. Captopril: a preliminary review of its pharmacological properties $\overrightarrow{\vec{B}}$ and therapeutic efficacy. Drugs 1980; 20: 409-52.

Requests for reprints to $\operatorname{Dr} \mathrm{J}$ I S Robertson, MRC Blood Pressure Unit, Western Infirmary, Glasgow G11 6NT. 